Article

\title{
Syngas Composition: Gasification of Wood Pellet with Water Steam through a Reactor with Continuous Biomass Feed System
}

\author{
Jerzy Chojnacki ${ }^{1, * \mathbb{D}}$, Jan Najser ${ }^{2}$, Krzysztof Rokosz ${ }^{1} \oplus$, Vaclav Peer $^{2}$, Jan Kielar ${ }^{2} \mathbb{D}$ \\ and Bogusława Berner ${ }^{1}$ \\ 1 Faculty of Mechanical Engineering, Koszalin University of Technology, Raclawicka Str.15-17, \\ 75-620 Koszalin, Poland; rokosz@tu.koszalin.pl (K.R.); boguslawa.berner@tu.koszalin.pl (B.B.) \\ 2 ENET Centre, VSB-Technical University of Ostrava, 17. Listopadu 2172/15, 70800 Ostrava, Czech Republic; \\ jan.najser@vsb.cz (J.N.); vaclav.peer@vsb.cz (V.P.); jan.kielar@vsb.cz (J.K.) \\ * Correspondence: jerzy.chojnacki@tu.koszalin.pl; Tel.: +48-94-3478-359
}

Received: 15 July 2020; Accepted: 22 August 2020; Published: 25 August 2020

check for updates

\begin{abstract}
Investigations were performed in relation to the thermal gasification of wood granulate using steam in an allothermal reactor with electric heaters. They studied the impact of the temperature inside the reactor and the steam flow rate on the percentage shares of $\mathrm{H}_{2}, \mathrm{CH}_{4}, \mathrm{CO}$, and $\mathrm{CO}_{2}$ in synthesis gas and on the calorific value of syngas. The tests were conducted at temperatures inside the reactor equal to 750,800 , and $850{ }^{\circ} \mathrm{C}$ and with a steam flow rate equal to $10.0,15.0$, and $20.0 \mathrm{~kg} \cdot \mathrm{h}^{-1}$. The intensity of gasified biomass was $20 \mathrm{~kg} \cdot \mathrm{h}^{-1}$. A significant impact of the temperature on the percentages of all the components of synthesis gas and a significant impact of the steam flow rate on the content of hydrogen and carbon dioxide in syngas were found. The highest percentage of hydrogen obtained was $43.3 \%$. The calorific value of the gas depended significantly on the temperature inside the reactor and the correlation between the temperature and the steam flow rate. Its maximum value was $13.3 \mathrm{MJ} \cdot \mathrm{m}^{-3}$ at $800{ }^{\circ} \mathrm{C}$. This paper also includes an assessment of the mutual correlations of the percentage shares of the individual synthesis gas components.
\end{abstract}

Keywords: biomass; steam gasification; allothermal reactor

\section{Introduction}

Biomass can be used as a biorenewable resource of many advanced materials [1], but it is also a very important fuel recognized as a renewable energy source [2]. The direct combustion of some plant products in boilers may release many substances that are harmful to the environment [3]. The gasification of biomass at high temperatures enables the purification of the resulting gases before combustion and makes it possible to control the emission of pollutants. Thermal gasification can help destroy waste (e.g., municipal waste) and convert the energy contained in it into heat or electricity [4]. The simple biomass gasification in reactors through partial combustion in a limited air stream results in the production of a gas with a lower heat value (LHV), usually below $6 \mathrm{MJ} \cdot \mathrm{Nm}^{-3}[5,6]$. Thermal gasification can be modified by introducing steam or oxygen instead of air into the gasifier, thus changing the composition of syngas produced [6-13]. In order to obtain the highest syngas energy value, attempts have been made to obtain the highest possible hydrogen and methane content and to minimize the share of carbon dioxide $[12,14]$. The high hydrogen content is achieved in the process of biomass gasification with the steam or thermal gasification of moist biomass [15-18].

The most popular raw materials used for the thermal gasification of biomass with the participation of water vapor is wood in various forms as sawdust, dust, chips, and granulates $[9,19,20]$. Apart from 
wood, typical cultivated energy crops [21] and waste biomass such as straw and hay [22,23], sewage sludge and manure [24-26] as well as biocarbon from previous biomass gasification may undergo steam gasification $[12,27]$. The raw materials for gasification may also include waste from the agri-food industry (e.g., oil production pomace [28], grape pomace [7], grain that was used in distilleries and in breweries [10,20,29], coffee hulls [30] and hazelnut shells [6]). Water steam gasification can be used not only in relation to biomass, but also in the process of the thermal gasification of hard coal, peat, and municipal waste as well as plastics [31-35]. Research is being carried out on the use of $\mathrm{CO}_{2}$ obtained from the combustion of syngas to increase the volume of syngas generated during the thermal gasification of municipal waste, particularly where increasing the $\mathrm{CO}_{2} /$ steam ratio can facilitate the production of both $\mathrm{CO}$ and $\mathrm{H}_{2}$ in the resulting gas [33]. Research is also being conducted on the co-gasification of hard coal with biomass where a synergy effect was observed. The volume of hydrogen produced is increasing in relation to the gasification tests of the biomass and coal itself [31].

As a result of high-temperature biomass gasification including water steam gasification, the resulting gas is contaminated, mainly with dust and tar. In order to be introduced into turbines and combustion engines, especially into fuel cells, it must be purified $[23,26]$. The filter sets composed from the cyclones and porous materials are used to treat the mechanical impurities from fine particles in syngas. Very high gasification temperatures [36] and catalysts introduced into the system can also be used to remove chemical impurities [37,38]. Calcium compounds such as dolomite are most commonly used as $\mathrm{CO}_{2}$ and tar sorbents in the gasification process [26].

The share of water vapor in the thermal gasification of biomass can take place in various types of gasifiers. These can be autothermal gasifiers, where biomass is heated by means of heat obtained from partial combustion, and allothermal gasifiers, where heat is supplied from external sources $[10,34,35]$. Biomass was gasified with water steam in fixed-bed gasifiers and in reactors with a continuous flow of biomass and produced gas $[21,23,31,38]$. Biomass steam gasification was tested in a reactor with free biomass fall and lower syngas take-off [27] and in mono or dual fluidized bed reactors $[8,9,24,29,33,39-41]$. In autothermal fluidized bed gasifiers, a gasifying medium is used to maintain the particles in the suspension of the gas to be gasified. This is usually air or oxygen. In the case of the allothermal gasifier where steam is the only gasifying medium, steam is also used to support the fluidization process and to lift the particles [11,35].

Since the purpose of thermal gasification with water steam is to obtain synthesis gas with the highest possible calorific value, the aim is to convert carbon dioxide produced during gasification into carbon monoxide and methane and to use it to enrich syngas with hydrogen. Exothermic and endothermic reactions occurring during this process are described by chemical equations cited by the authors in $[11,21,25,35,42]$. The most important chemical reaction equations are the following:

Char oxidation:

$$
\mathrm{C}+\mathrm{O}_{2} \rightarrow \mathrm{CO}_{2}
$$

Boudouard reaction:

$$
\mathrm{CO}_{2}+\mathrm{C} \leftrightarrow 2 \mathrm{CO}
$$

Water-gas shift reaction:

$$
\mathrm{CO}+\mathrm{H}_{2} \mathrm{O} \leftrightarrow \mathrm{CO}_{2}+\mathrm{H}_{2}
$$

Water-gas reaction:

$$
\mathrm{C}+\mathrm{H}_{2} \mathrm{O} \leftrightarrow \mathrm{CO}+\mathrm{H}_{2}
$$

Thermal cracking:

$$
\mathrm{C}_{\mathrm{n}} \mathrm{H}_{\mathrm{m}} \rightarrow \mathrm{C}+\mathrm{C}_{\mathrm{x}} \mathrm{H}_{\mathrm{y}}+\mathrm{H}_{2}
$$

Based on the thermodynamic equilibrium equations, mass and energy balances, and dedicated computer software, attempts have been made to model the gasification processes, while taking into account the individual stages of the process [40,42-44]. The results of the experimental and model investigations that have been conducted to date indicate that there are optimal ranges for the 
steam content in the gasifying medium. This was found, among others, during gasification with an air-steam mixture [7]. The results demonstrated that the composition of synthesis gas produced during water steam gasification and its calorific value as well as the relations between the shares of $\mathrm{H}_{2}$ and $\mathrm{CO}$ contained therein, may depend on the gasification temperature and the steam to biomass ratio $[11,13,18,40]$.

Many experiments concerning biomass gasification with steam were carried out in autothermal reactors with the use of air or oxygen mostly in small laboratory gasifiers. The novelty of this work is that the research was carried out in an installation with a large reactor with a continuous biomass feed system to obtain pure syngas with a high concentration of methane and hydrogen.

The aim of the research was to determine the influence of temperature in the allothermal flow reactor and the influence of the steam flow rate to the reactor, to the synthesis gas composition and its lower heat value. Steam together with the heat generated in the reactor heating sets were the gasifying factors. An analysis of the percentage shares of the following gases was planned: $\mathrm{H}_{2}, \mathrm{CH}_{4}, \mathrm{CO}, \mathrm{C}_{\mathrm{m}} \mathrm{H}_{\mathrm{n}}$ as well as $\mathrm{CO}_{2}$ and $\mathrm{O}_{2}$ in the expected synthesis gas composition.

\section{Materials and Methods}

\subsection{Gasification Installation}

The research was carried out on an installation for thermal biomass gasification located in the Energy Research Center of the VŠB-Technical University of Ostrava, which produces syngas used to drive power generators. The installation consisted of an electrically heated reactor with a continuous supply of biomass and steam, a set of devices for cleaning and cooling synthesis gas, and a gas composition analyzer. A view of the gasification reactor is shown in Figure 1.

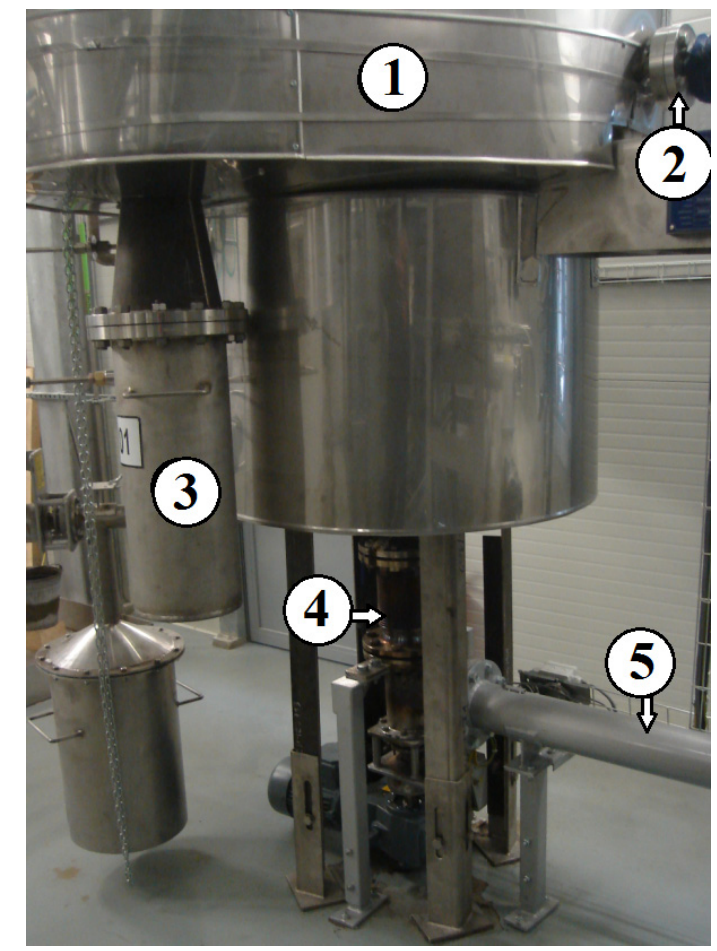

Figure 1. Reactor view: 1-bottom of the reactor, 2-steam pipe, 3-ash collection, 4-vertical screw conveyor, 5-horizontal screw conveyor.

The reactor was heated from below by means of a $20 \mathrm{~kW}$ oval electric heater and from above by means of five bar heaters with a total power of $35 \mathrm{~kW}$. Thermocouples for temperature measurements were installed in the lower and upper parts of the reactor to allow temperature adjustments inside the reactor. During the tests, the temperature was recorded in the upper part of the reactor, directly 
over the bed. The material subjected to gasification as the biomass was wood pellets, fed by means of a biomass feeder, with flow scales installed to control the rate of the biomass feed. From the feeder, the pellets were fed into the reactor from below, onto a moving grate, using horizontal and vertical screw conveyors. After the biomass was incinerated, the ash fell from the grate to the bottom of the reactor, from which it was removed by means of a screw conveyor to a closed metal container. The tank was emptied at the end of the experiment. The design of the reactor prevented any uncontrolled air from entering it from the outside.

The steam was produced by means of an electric generator. The rate of steam flow into the generator was adjusted by valves and by means of a flow meter mounted on a pipe with water flowing into the steam generator. The temperature of the water vapor supplied from the generator to the reactor was $650^{\circ} \mathrm{C}$. A diagram of the complete biomass thermal gasification plant including the equipment for gas treatment and analysis is shown in Figure 2.

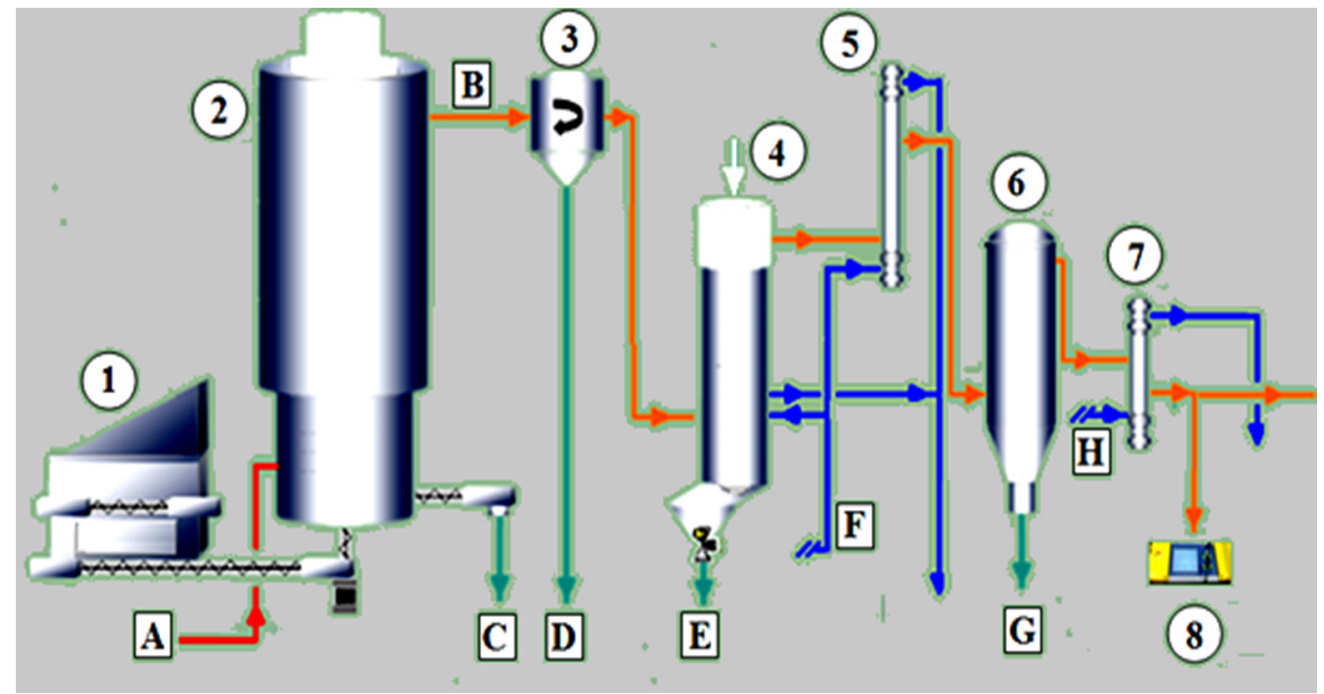

Figure 2. Diagram of the biomass gasification plant: 1-pellet dispenser, 2-reactor, 3-cyclone separator, 4-dolomite reactor, 5-water cooler, 6-high temperature filter, 7-cooler, 8-syngas analyzer, A-steam, B-gas, C-ash, D-dust, E-used dolomite, F-water, G-dust, H-ice water.

The syngas produced in the installation was designed to drive a power generator driven by a combustion engine. In order to meet the requirements concerning the purity of the gas used to power the engine, the syngas was cleaned by means of a set of multiple devices [45]. Dust was removed by means of a cyclone separator (marked with the number 3) and with a dust filter (No. 6). A reactor with a dolomite catalyst was used to eliminate tar from the gas. The gas temperature was reduced by passing it through a water cooler fed with running water from a water system and ice water coolers. The installation was designed and constructed in cooperation with the Czech company ATEKO a.s.

\subsection{Materials}

A constant flow rate of the wood pellet into the generator was accepted for the purpose of this study, which was $20 \mathrm{~kg} \cdot \mathrm{h}^{-1}$. The laboratory-determined physical parameters of the pellets are shown in Table 1. The elemental composition of the granulate is shown in Table 2.

The flow rate of steam into the generator was adjusted to $10.0,15.0$, and $20.0 \mathrm{~kg} \cdot \mathrm{h}^{-1}$. The ratio of the steam rate to the rate of the biomass of pellets introduced into the $\mathrm{S} / \mathrm{B}$ reactor was $0.5,0.75$, and 1.0 , respectively. 
Table 1. Physical parameters of the pellet.

\begin{tabular}{ccc}
\hline Parameter & Size & Symbol \\
\hline Diameter & 6 & $\mathrm{~mm}$ \\
Length & $10-30$ & $\mathrm{~mm}$ \\
Bulk density & 650 & $\mathrm{~kg} \cdot \mathrm{m}^{-3}$ \\
Humidity & 8.67 & $\% \mathrm{hm}$. \\
Calorific value & 17.5 & $\mathrm{MJ} \cdot \mathrm{kg}^{-1}$ \\
Ash content & $<0.6$ & $\%$ \\
Attrition & 2 & $\%$ \\
\hline
\end{tabular}

Table 2. Elemental composition of the granulate.

\begin{tabular}{cc}
\hline Ingredients & Contents \% \\
\hline $\mathrm{C}$ & 47.43 \\
$\mathrm{H}$ & 6.10 \\
$\mathrm{~N}$ & 0.04 \\
$\mathrm{O}$ & 40.00 \\
$\mathrm{~S}$ & 0.05 \\
$\mathrm{Cl}$ & 0.013 \\
Ash & 0.39 \\
\hline
\end{tabular}

\subsection{Methods}

A Portable Syngas Analyzer Gas 3100 was used to measure the percentage composition of the generator gas. The analyzer was connected to a pipe with cooled and purified gas coming out of the installation. The gas samples were collected by means of a ball valve probe equipped with a heated fiberglass filter trap, where solids and some tar particles were captured. Then, the gas flowed through vessels filled with isopropanol, where tar residues were removed from the gas. The gas then passed through three covered dishes placed in a freezer, where all the remaining organic substances and moisture were precipitated. With the help of the analyzer, the contents of $\mathrm{CO}, \mathrm{CO}_{2}, \mathrm{CH}_{4}, \mathrm{H}_{2}, \mathrm{O}_{2}$, and $\mathrm{C}_{\mathrm{n}} \mathrm{H}_{\mathrm{m}}$ in the synthesis gas were recorded continuously. The tests of the gas composition were performed with three temperatures set inside the reactor at 750,800 , and $850^{\circ} \mathrm{C}$.

All parameters were measured continuously during the experiment and recorded by a computer. The test measurements were made after the set temperature inside the reactor had been reached and stabilized and after the steam flow rate and gas discharge pressure had been reached. The data were recorded once every minute for the measurement period of $10 \mathrm{~min}$.

The research was carried out on at installation for thermal biomass gasification located in the Energy Research Center of the VŠB-Technical University of Ostrava, which produces syngas used to drive power generators.

\section{Results and Discussion}

The results of all the measurements of the concentrations of the gases tested, with each temperature and with each rate of steam flow, showed hydrogen, methane, hydrocarbon, carbon dioxide, and carbon monoxide contents and no free oxygen $\mathrm{O}_{2}$ content was found. The presence of $\mathrm{C}_{n} \mathrm{H}_{m}$ hydrocarbons in syngas was negligible, never exceeding $0.8 \%$. At a temperature of $850{ }^{\circ} \mathrm{C}$, the content of this gas was equal to " 0 " for all the vapor flow rates and did not exceed $0.2 \%$ at $750{ }^{\circ} \mathrm{C}$; hence, a decision was made to omit its content as a separate gas for further analyses and to add the $\mathrm{C}_{n} \mathrm{H}_{m}$ concentrations determined in the syngas to the $\mathrm{CH}_{4}$ concentration.

The averaged measurement results for the determined values of the temperature in the reactor and the steam flow rates are presented in Table 3. The results of the measurements of the percentage share of hydrogen, methane, carbon dioxide, and carbon monoxide in synthesis gas underwent a two-factor analysis of variance in order to determine the significance of the impact of the following: 
the steam outflow rate in the reactor and the temperature inside the reactor on the changes in the concentration of these components in the gas obtained.

Table 3. Averaged measurement results with standard deviations.

\begin{tabular}{cccccccccc}
\hline \multirow{2}{*}{$\begin{array}{c}\text { Temp } \\
{ }^{\circ} \mathbf{C}\end{array}$} & $\begin{array}{c}\text { Steam Flow } \\
\text { Ratio kg.h }\end{array}$ & \multicolumn{2}{c}{$\mathbf{H}_{\mathbf{2}} \%$} & \multicolumn{2}{c}{$\mathbf{C H}_{\mathbf{4}} \%$} & \multicolumn{2}{c}{$\mathbf{C O}_{\mathbf{2}} \%$} & \multicolumn{2}{c}{$\mathbf{C O} \%$} \\
\cline { 3 - 9 } & Cont. & $\begin{array}{c}\text { Stand. } \\
\text { Dev. }\end{array}$ & Cont. & $\begin{array}{c}\text { Stand. } \\
\text { Dev. }\end{array}$ & Cont. & $\begin{array}{c}\text { Stand. } \\
\text { Dev. }\end{array}$ & Cont. & $\begin{array}{c}\text { Stand. } \\
\text { Dev. }\end{array}$ \\
\hline 750 & 10 & 44.56 & 0.24 & 13.44 & 0.13 & 22.34 & 0.21 & 19.66 & 0.33 \\
750 & 15 & 43.34 & 0.49 & 13.72 & 0.29 & 21.64 & 0.75 & 21.30 & 0.88 \\
750 & 20 & 42.60 & 0.42 & 14.15 & 0.28 & 22.88 & 0.74 & 20.37 & 0.51 \\
800 & 10 & 38.30 & 5.10 & 15.56 & 1.54 & 23.87 & 3.74 & 22.27 & 7.55 \\
800 & 15 & 35.92 & 1.79 & 16.90 & 0.58 & 22.78 & 0.21 & 24.40 & 1.29 \\
800 & 20 & 33.87 & 0.78 & 17.08 & 0.39 & 23.69 & 0.73 & 25.37 & 1.19 \\
850 & 10 & 36.36 & 2.17 & 12.34 & 1.52 & 29.06 & 2.50 & 22.24 & 3.17 \\
850 & 15 & 35.34 & 0.45 & 11.02 & 0.47 & 31.40 & 0.86 & 22.24 & 0.85 \\
850 & 20 & 35.58 & 0.27 & 10.99 & 0.16 & 34.00 & 0.42 & 19.43 & 0.44 \\
\hline
\end{tabular}

\subsection{Impact of the Steam Flow Rate on the Concentration of Synthesis Gas Components}

The impact of the steam flow rate on the concentrations of synthesis gas components is shown in Figure 3, which presents the average percentage shares of synthesis gas components calculated on the basis of the values obtained for all tested temperatures.

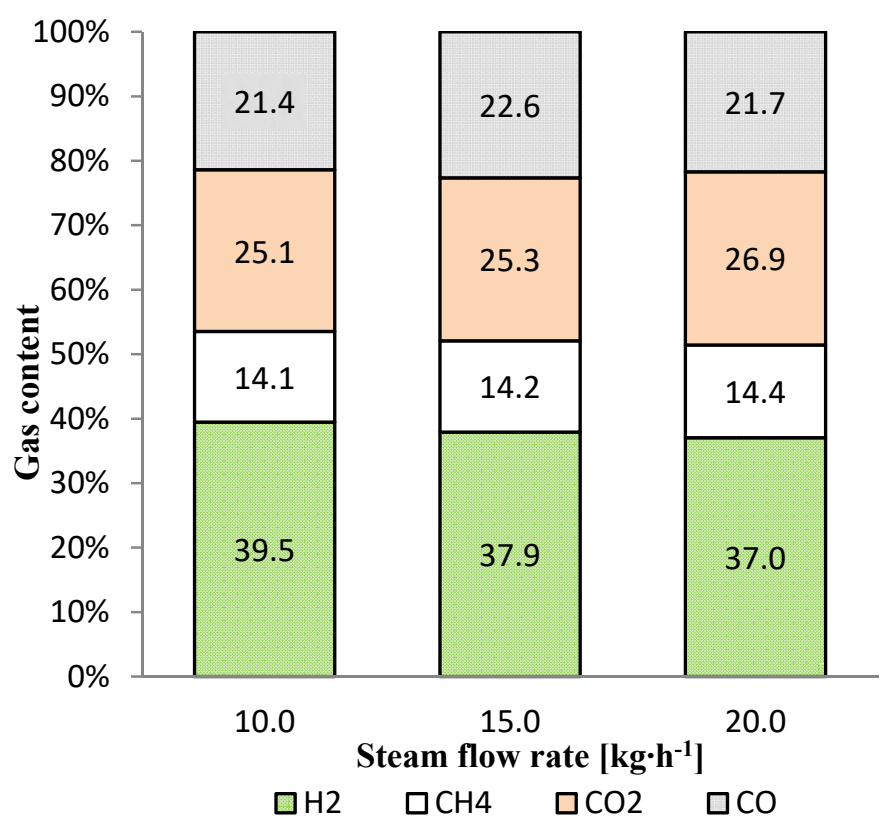

Figure 3. Impact of the rate of steam outflow on the composition of synthesis gas (the least significant difference at the significance level $p<0.05$, for: $\mathrm{H}_{2}=1.0 \%, \mathrm{CH}_{4}=0.4 \%, \mathrm{CO}_{2}=0.8 \%, \mathrm{CO}=1.5 \%$ ).

The Figure 3 shows the calculated values of the least significant differences (LSD) for each of these gases. These values make it possible to find the value of the steam flow rate at which a significant difference in the gas composition occurred.

No significance of the impact of the steam flow rate on the percentage of $\mathrm{CO}$ and $\mathrm{CH}_{4}$ in the synthesis gas was found. However, the impact of the steam flow rate on the $\mathrm{CO}_{2}$ and $\mathrm{H}_{2}$ concentrations was found to be significant. An increase in the steam flow rate in the reactor caused an increase in carbon dioxide and a decrease in hydrogen content. The optimum hydrogen content, an average of $39.5 \%$, was observed with the steam flow rate of $10 \mathrm{~kg} \cdot \mathrm{h}^{-1}$, which corresponded to the $\mathrm{S} / \mathrm{B}$ ratio of 0.5 . Similar results were presented in $[25,31]$. In other studies on the thermal gasification of biomass with 
steam, with or without air, the maximum share of hydrogen content in syngas was obtained at higher $\mathrm{S} / \mathrm{B}$ values $[7,10,11,40]$.

\subsection{Impact of the Temperature on the Concentration of Synthesis Gas Components}

Based on the values obtained for all tested steam flow ratios, the average percentage shares of the gases included in the synthesis gas were determined for particular temperatures in order to assess the significance of the impact of the temperature in the generator on the composition of the gas. The least significant differences were determined for each of these syngas ingredients at the significance level of $p<0.05$.

Using the calculated values of the least significant differences to compare the changes in the contents of the individual gases depending on the temperature inside the reactor, it can be noted that a significant decrease in hydrogen content in the synthesis gas occurred between 750 and $800{ }^{\circ} \mathrm{C}$. The highest percentage share of $\mathrm{H}_{2}$ in the synthesis gas was $43.3 \%$ and it occurred at the lowest reactor temperature of $700{ }^{\circ} \mathrm{C}$. The methane content of synthesis gas increased significantly between 750 and $800^{\circ} \mathrm{C}$ and then decreased between 800 and $850^{\circ} \mathrm{C}$. The carbon dioxide content increased significantly between 800 and $850{ }^{\circ} \mathrm{C}$. The carbon monoxide content increased significantly at $800{ }^{\circ} \mathrm{C}$, and then returned to the previous level at $850^{\circ} \mathrm{C}$ (Figure 4).

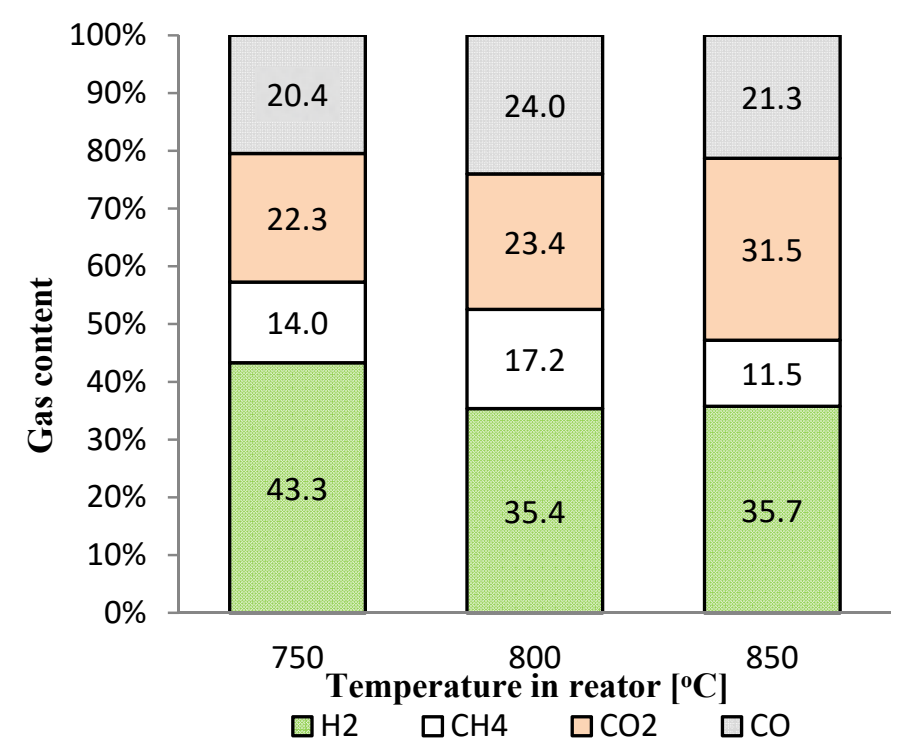

Figure 4. Impact of the temperature in the reactor on the composition of the generated gas (the least significant difference at a significance level $p<0.05$ for $\mathrm{H}_{2}=1.0 \%, \mathrm{CH}_{4}=0.4 \%, \mathrm{CO}_{2}=0.8 \%, \mathrm{CO}=1.5 \%$ ).

\subsection{Impact of Reactor Temperature and the Steam Flow Rate on the Syngas Heat Value}

The results of the syngas calorific value determined with the GAS 3100 Syngas gas analyzer were also covered by a two-factor variance analysis to calculate the significance of the impact of the steam flow rate and the temperature inside the reactor on the syngas energy value. The analysis demonstrated the significance of the impact of the temperature and the significance of the impact of the temperature and steam flow rate correlation on the syngas calorific value. A diagram that shows the impact of the temperature in the reactor on the lower heat value of synthesis gas is shown in Figure 5.

No significance was found in the impact of the steam flow rate alone on the changes in the syngas heat value. The maximum lower heat value of the synthesis gas was obtained at $800{ }^{\circ} \mathrm{C}$. A further increase in temperature up to $850^{\circ} \mathrm{C}$ in the generator resulted in a decrease in the heat value of the gas generated. By analyzing the composition of syngas at this temperature, it can be concluded that the decrease in the energy value was influenced by the increase in the percentage of $\mathrm{CO}_{2}$ and the decrease in the $\mathrm{CO}$ and $\mathrm{CH}_{4}$ contents. 


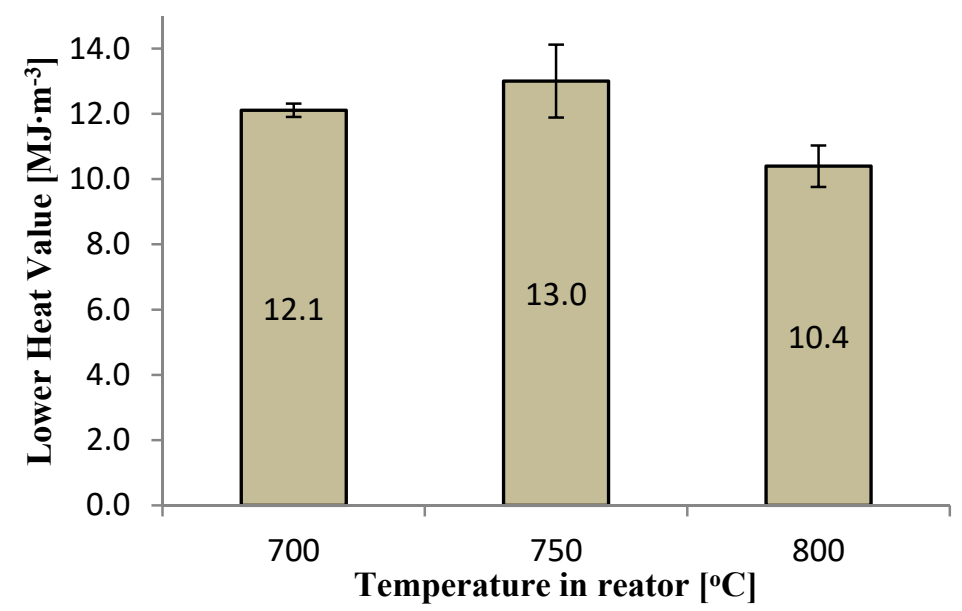

Figure 5. Impact of the temperature in the reactor on the syngas lower heat value.

The impact of the correlation between the reactor temperature and the steam outflow rate on the syngas heat value is shown in Figure 6. The calorific value of synthesis gas obtained at the level of 13.3 MJ.m $\mathrm{m}^{-3}$ at the temperature of $800{ }^{\circ} \mathrm{C}$, and the steam inflow rate of 15.0 and $20.0 \mathrm{~kg} \cdot \mathrm{h}^{-1}$ was typical for the thermal gasification of biomass with these conditions $[6,13]$.

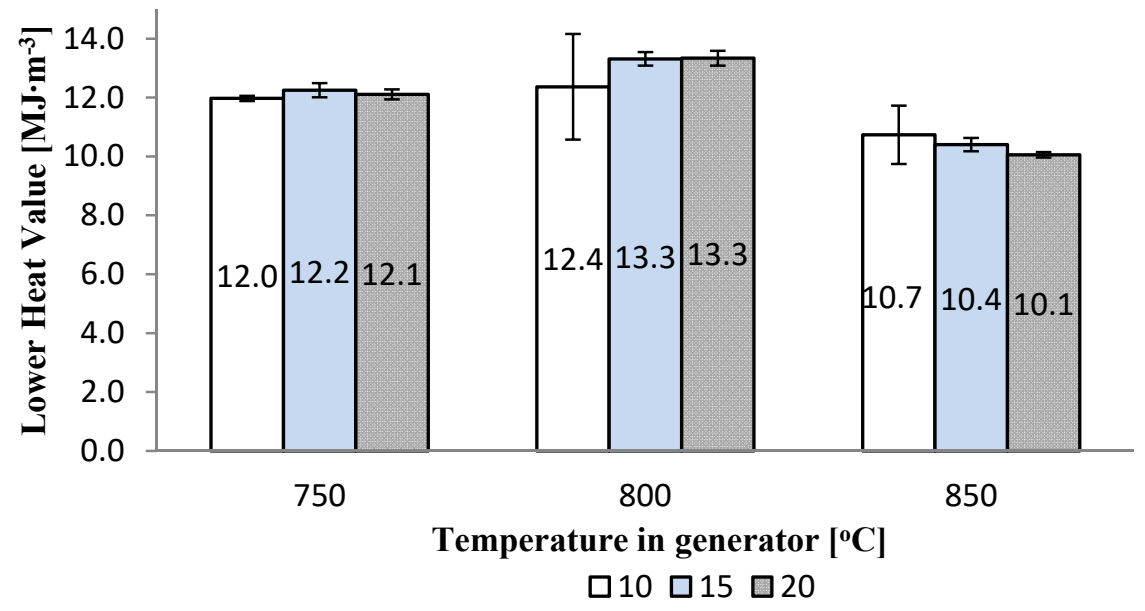

Figure 6. Impact of temperature in the generator and the steam outflow rate $\left(10 ; 15 ; 20 \mathrm{~kg} \cdot \mathrm{h}^{-1}\right)$ on the syngas lower heat value.

\subsection{Correlations between the Content of the Individual Syngas Components}

The basic components of gasified wood biomass and introduced water vapor such as $\mathrm{O}_{2}, \mathrm{H}_{2}$, and $\mathrm{C}$ were in the reactor. The amount and the percentage content of the produced gases that constitute the components of the syngas obtained in the reactor result directly from the mass flow rate of steam and biomass, the temperature in the reactor, and the chemical processes described by Equations (1)-(5), which took place during the gasification in the reactor. An analysis of the mutual correlations between the percentage contents of individual gases was carried out, taking into account the results of all measurements. Figures 7 and 8 show the percentage changes of carbon monoxide and carbon dioxide contents in the syngas with an increasing methane percentage content. 


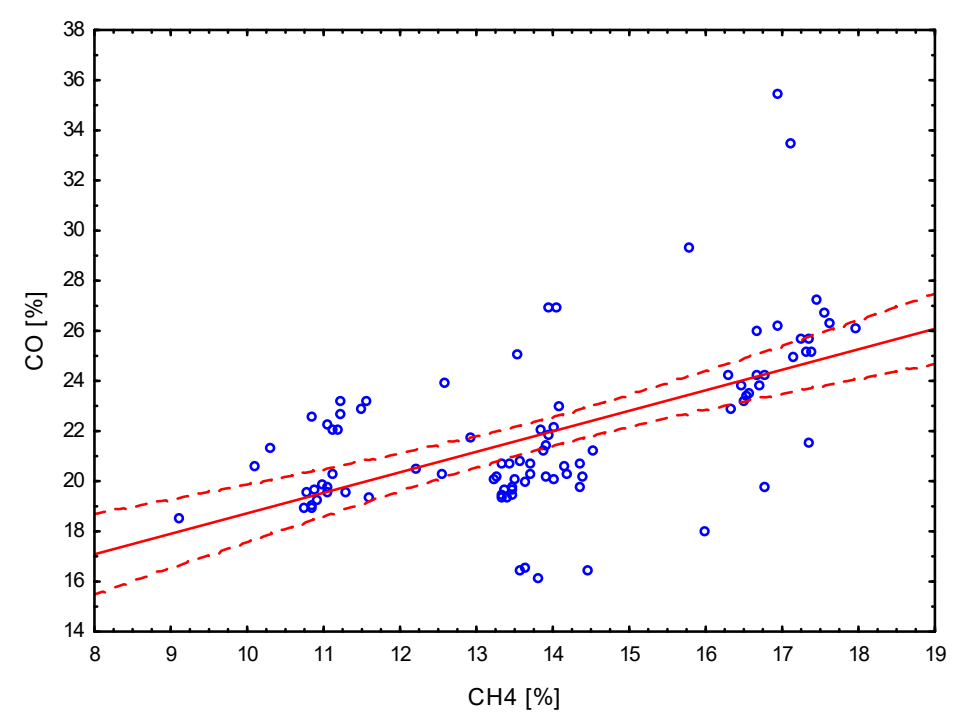

Figure 7. Correlation between percentage content of $\mathrm{CO}$ and percentage content of $\mathrm{CH}_{4}$.

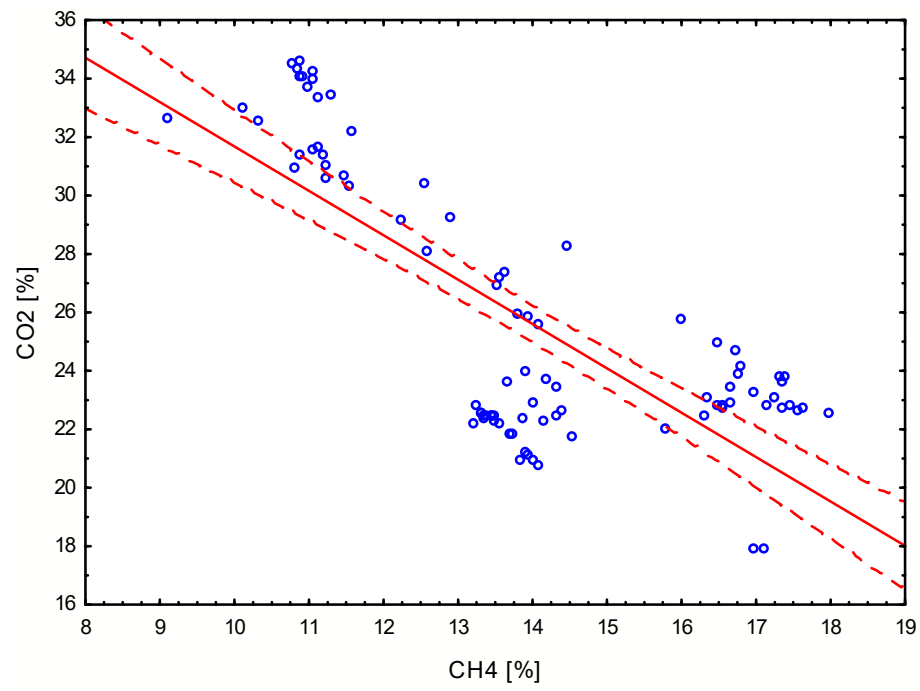

Figure 8. Correlation between percentage content of $\mathrm{CO}_{2}$ and percentage content of $\mathrm{CH}_{4}$.

The $\mathrm{CO}$ content increased with the growing $\mathrm{CH}_{4}$ content. This relationship is described in the following regression equation:

$$
\mathrm{CO}=10.552+0.81718 \cdot \mathrm{CH}_{4}
$$

with the calculated correlation coefficient $\mathrm{r}=0.56371$ at the significance level of $p=0.95$.

In the case of $\mathrm{CO}_{2}$, the content of this gas decreased significantly as the $\mathrm{CH}_{4}$ content increased. The regression equation is determined as follows:

$$
\mathrm{CO}_{2}=46.859-1.518 \cdot \mathrm{CH}_{4}
$$

with the correlation coefficient $\mathrm{r}=-0.7606$, at the significance level $p=0.95$.

The relation between the $\mathrm{CO}_{2}$ and $\mathrm{CO}$ content is shown in Figure 9. The following regression equation was determined:

$$
\mathrm{CO}_{2}=37.385-0.5313 \cdot \mathrm{CO}
$$

with the correlation coefficient $\mathrm{r}=-0.3859$ at the significance level of $p=0.95$.

An attempt to find the relation between $\mathrm{CH}_{4}$ and $\mathrm{H}_{2}$ is shown in Figure 10. 


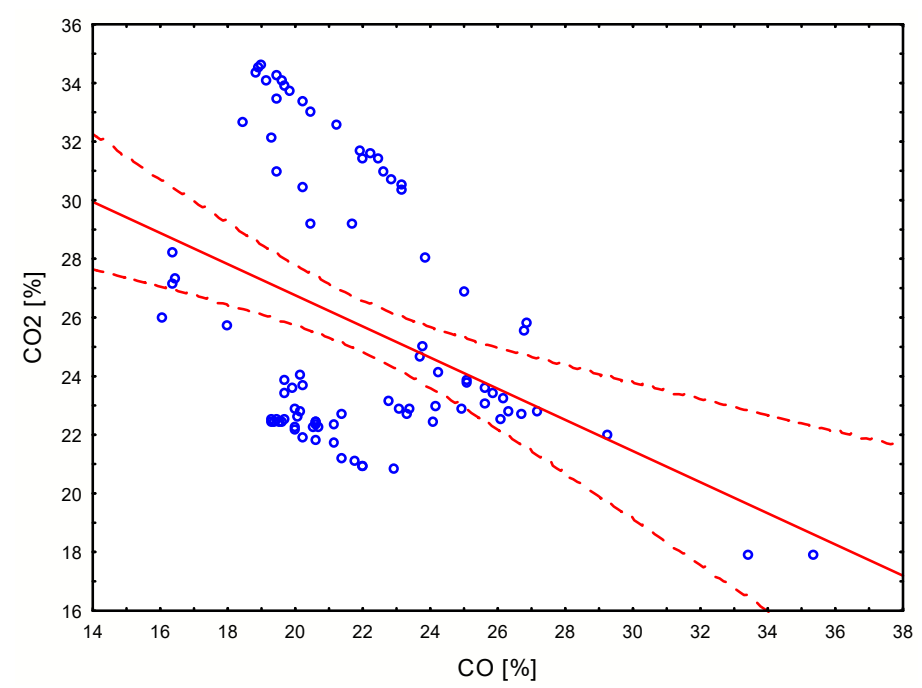

Figure 9. Correlation between the percentage of $\mathrm{CO}_{2}$ and $\mathrm{CO}$.

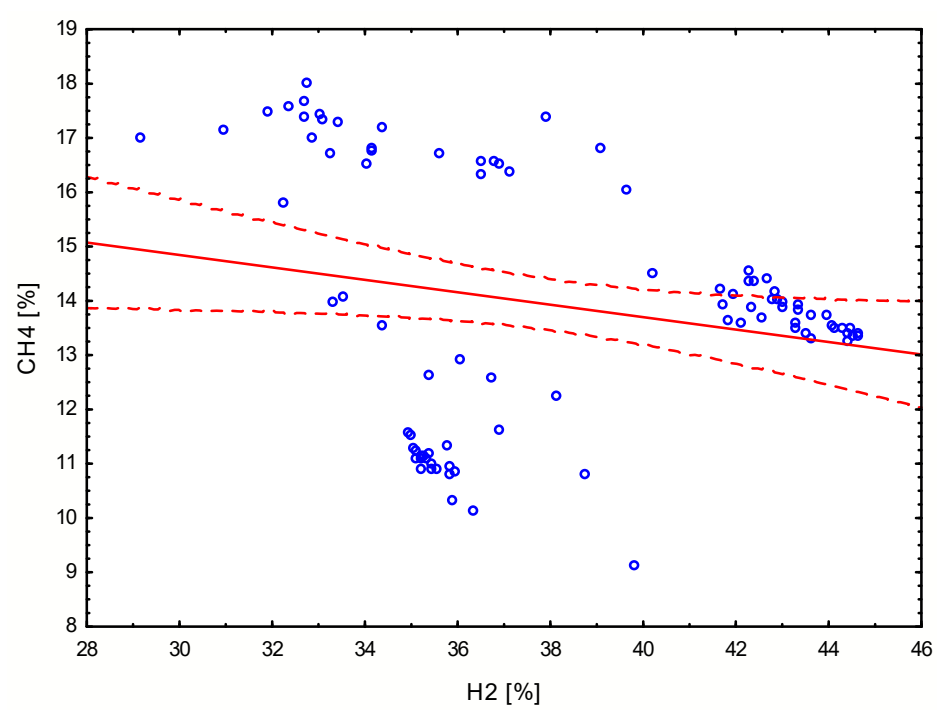

Figure 10. Correlation between the percentage content of $\mathrm{CH}_{4}$ and $\mathrm{H}_{2}$.

The following regression equation was determined:

$$
\mathrm{CH}_{4}=18.278-0.1145 \cdot \mathrm{H}_{2}
$$

with the correlation coefficient $\mathrm{r}=-0.2155$ at the significance level of $p=0.95$.

Correlations between the carbon monoxide and carbon dioxide contents, depending on the proportion of the hydrogen share, are shown in Figures 11 and 12. The relations can be described by the following regression equations:

$$
\mathrm{CO}=42.023-0.5270 \cdot \mathrm{H}_{2}
$$

with the correlation coefficient $\mathrm{r}=-0.6842$ at the significance level of $p=0.95$,

$$
\mathrm{CO}_{2}=38.841-0.3435 \cdot \mathrm{H}_{2}
$$

with the correlation coefficient $r=-0.3239$ at the significance level of $p=0.95$.

The determined equations demonstrate a decrease in the carbon monoxide and carbon dioxide contents as the hydrogen content of the syngas increases. 
Strong relations, with a correlation coefficient higher than 0.5 , occurred between the $\mathrm{CO}$ and $\mathrm{CO}_{2}$ contents in relation to the $\mathrm{CH}_{4}$ content, and between the $\mathrm{CO}$ content in relation to the $\mathrm{H}_{2}$ content.

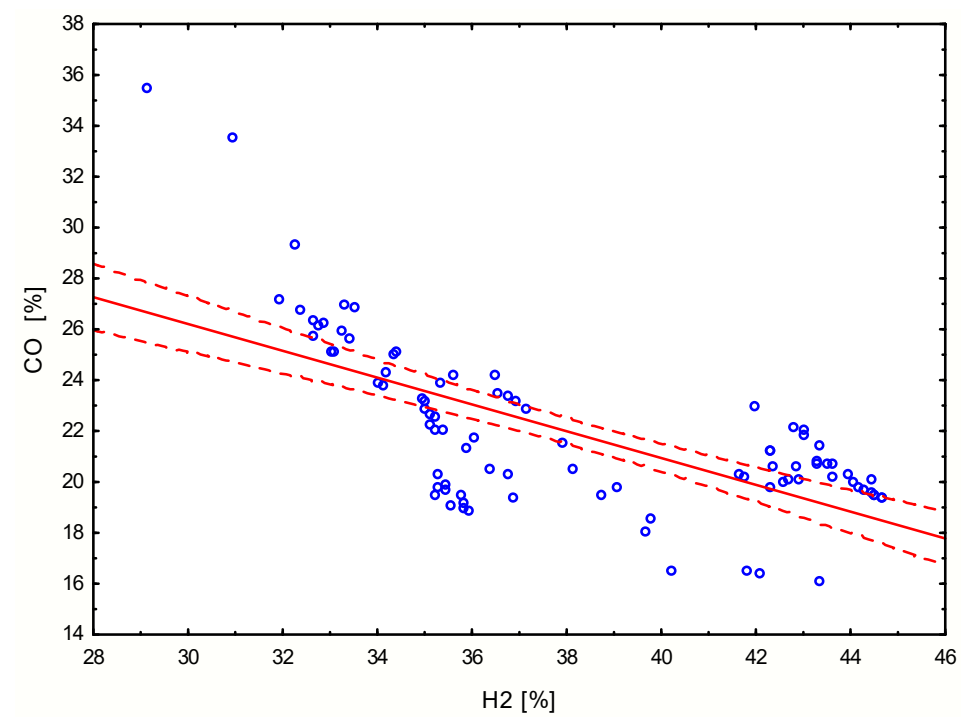

Figure 11. Correlation between percentage of $\mathrm{CO}$ and $\mathrm{H}_{2}$ contents.

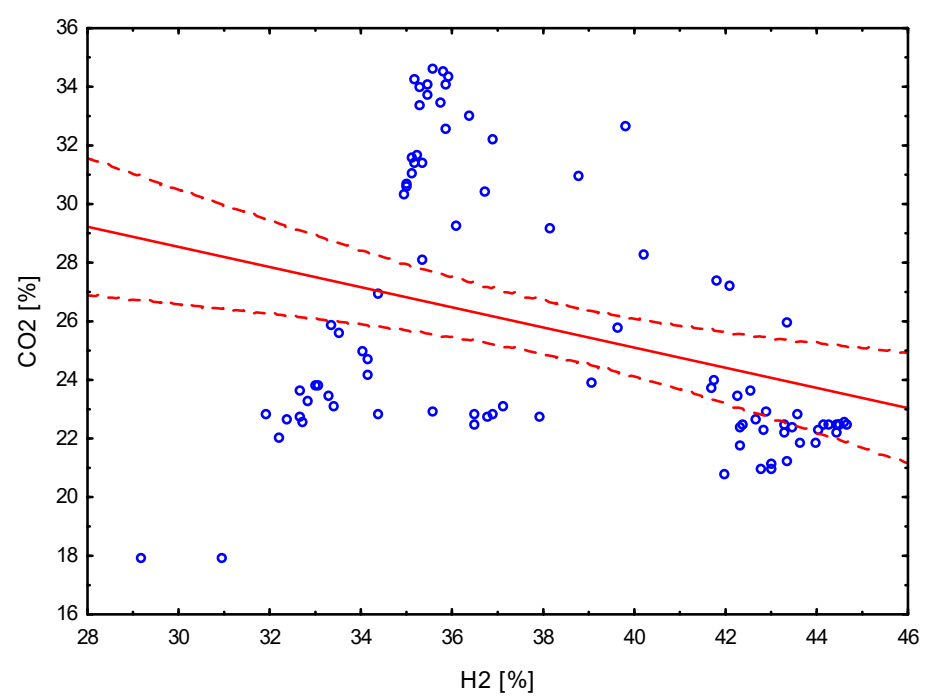

Figure 12. Correlation between percentage of $\mathrm{CO}_{2}$ and $\mathrm{H}_{2}$ contents.

\section{Conclusions}

The main components of the synthesis gas obtained as the result of the thermal gasification of wood granulate with steam are represented by the following gases: $\mathrm{CO}, \mathrm{CO}_{2}, \mathrm{CH}_{4}$, and $\mathrm{H}_{2}$. The value of the content of these gases in the gas generated was significantly influenced by the temperature in the gas generator. An increase in the temperature between 750 and $850^{\circ} \mathrm{C}$ had a significant impact on the decrease of the $\mathrm{H}_{2}, \mathrm{CH}_{4}$, and $\mathrm{CO}$ content and on the increase of the $\mathrm{CO}_{2}$ content.

A significant impact of the steam flow rate on the concentration of $\mathrm{H}_{2}$ and $\mathrm{CO}_{2}$ in the synthesis gas was found. An increase in the steam flow rate in the generator caused a decrease in the share of hydrogen and an increase in the share of carbon dioxide in the syngas.

There was a significant impact of the temperature of the gas generator on the calorific value of the syngas. The highest calorific value of the synthesis gas was obtained at $800^{\circ} \mathrm{C}$.

This study has documented the existence of strong correlations between the carbon monoxide and carbon dioxide contents and methane content as well as between the carbon monoxide content and hydrogen content. 
The research on the thermal gasification of wood granulate using steam, carried out in an electrically heated flow reactor, has confirmed the significance of the impact of the following factors: the flow rate of steam supplied to the reactor and the temperature inside the reactor on the percentage share of the components of the syngas produced such as $\mathrm{H}_{2}, \mathrm{CH}_{4}, \mathrm{CO}$, and $\mathrm{CO}_{2}$. The research has demonstrated a possibility of adjusting the values of these factors while obtaining the required syngas composition and considering its maximum calorific value.

Author Contributions: Conceptualization, J.C. and J.N.; methodology, J.C., J.N., K.R. and V.P.; software, B.B.; validation, J.C., K.R. and J.K.; formal analysis, J.K. and K.R.; data curation, J.C. and V.P.; writing-original draft preparation, J.C., V.P. and J.N.; writing-review and editing, J.C., K.R., B.B. and J.K.; visualization, B.B.; supervision, J.N.; project administration, J.C.; funding acquisition, J.C. and J.K. All authors have read and agreed to the published version of the manuscript.

Funding: The research was performed within the framework of a project of bilateral exchange of researchers between the Republic of Poland and the Czech Republic titled "Use of catalysts to reduce emissions from the combustion of waste biomass" (reference no: PPN/BIL/2018/1/00074) co-financed in Poland by the NAWA, National Agency of Academic Exchange and supported by the Ministry of Education, Youth, and Sports of the Czech Republic under OP RDE grant number CZ.02.1.01/0.0/0.0/16_019/0000753 “Research center for low-carbon energy technologies".

Acknowledgments: The authors would like to thank Associate Professor Tadeas Ochodek, Director of the Energy Research Center of VŠB-Technical University of Ostrava, for making the laboratory available for carrying out tests and providing assistance during their performance.

Conflicts of Interest: The authors declare no conflict of interest.

\section{References}

1. Ates, B.; Koytepe, S.; Ulu, A.; Gurses, C.; Thakur, V.K. Chemistry, Structures, and Advanced Applications of Nanocomposites from Biorenewable Resources. Chem. Rev. 2020. [CrossRef] [PubMed]

2. Lisy, M.; Lisa, H.; Jecha, D.; Balas, M.; Krizan, P. Characteristic properties of alternative biomass fuels. Energies 2020, 13, 1448. [CrossRef]

3. Chojnacki, J.; Ondruska, J.; Kuczynski, W.; Soos, L.; Balasz, B. Emissions from the combustion of solid biofuels. In Proceedings of the 9th International Scientific Symposium on Farm Machinery and Process Management in Sustainable Agriculture, Lublin, Poland, 22-24 November 2017; pp. 70-75.

4. Balas, M.; Lisy, M.; Kracik, P.; Pospisil, J. Municipal solid waste gasification within waste-to-energy processing. MM Sci. J. 2017, 1783-1788. [CrossRef]

5. Najser, J.; Ochodek, T.; Chlond, R. Functioning of installation for a biomass gasification and economic aspects of electricity generation. Rynek Energii 2009, 6, 68-74.

6. Gallucci, F.; Liberatore, R.; Sapegno, L.; Volponi, E.; Venturini, P.; Rispoli, F.; Paris, E.; Carnevale, M.; Colantoni, A. Influence of oxidant agent on syngas composition: Gasification of hazelnut shells through an updraft reactor. Energies 2020, 13, 102. [CrossRef]

7. Hernández, J.J.; Aranda, G.; Barba, J.; Mendoza, J.M. Effect of steam content in the air-steam flow on biomass entrained flow gasification. Fuel Process. Technol. 2012, 99, 43-55. [CrossRef]

8. Campoy, M.; Gómez-Barea, A.; Vidal, F.B.; Ollero, P. Air-steam gasification of biomass in a fluidised bed: Process optimisation by enriched air. Fuel Process. Technol. 2009, 90, 677-685. [CrossRef]

9. Lv, P.M.; Xiong, Z.H.; Chang, J.; Wu, C.Z.; Chen, Y.; Zhu, J.X. An experimental study on biomass air-steam gasification in a fluidized bed. Bioresour. Technol. 2004, 95, 95-101. [CrossRef]

10. Ferreira, S.; Monteiro, E.; Brito, B.; Castro, C.; Calado, L.; Vilarinho, C. Experimental analysis of brewers' spent grains steam gasification in an allothermal batch reactor. Energies 2019, 12, 912. [CrossRef]

11. Niu, Y.; Han, F.; Chen, Y.; Lyu, Y.; Wang, L. Experimental study on steam gasification of pine particles for hydrogen-rich gas. J. Energy Inst. 2017, 90, 715-724. [CrossRef]

12. Sattar, A.; Leeke, G.A.; Hornung, A.; Wood, J. Steam gasification of rapeseed, wood, sewage sludge and miscanthus biochars for the production of a hydrogen-rich syngas. Biomass Bioenergy 2014, 69, 276-286. [CrossRef]

13. Jangsawang, W.; Klimanek, A.; Gupta, A.K. Enhanced yield of hydrogen from wastes using high temperature steam gasification. J. Energy Resour. Technol. 2006, 128, 179-185. [CrossRef] 
14. Acharya, B.; Dutta, A.; Basu, P. An investigation into steam gasification of biomass for hydrogen enriched gas production in presence of CaO. Int. J. Hydrogen Energy 2010, 35, 1582-1589. [CrossRef]

15. Gao, N.; Li, A.; Quan, C. A novel reforming method for hydrogen production from biomass steam gasification. Bioresour. Technol. 2009, 100, 4271-4277. [CrossRef] [PubMed]

16. Valente, A.; Iribarren, D.; Gálvez-Martos, J.L.; Dufour, J. Robust eco-efficiency assessment of hydrogen from biomass gasification as an alternative to conventional hydrogen: A life-cycle study with and without external costs. Sci. Total Environ. 2019, 650, 1465-1475. [CrossRef] [PubMed]

17. Schmieder, H.; Abeln, J.; Boukis, N.; Dinjus, E.; Kruse, A.; Kluth, M.; Petrich, G.; Sadri, E.; Schacht, M. Hydrothermal gasification of biomass and organic wastes. J. Supercrit. Fluids 2000, 17, 145-153. [CrossRef]

18. Siwal, S.S.; Zhang, O.; Sun, C.; Thakur, S.; Gupta, V.K.; Thakur, V.K. Energy production from steam gasification processes and parameters that contemplate in biomass gasifier-A review. Bioresour. Technol. 2020, 297, 1-11.

19. Umeki, K.; Yamamoto, K.; Namioka, T.; Yoshikawa, K. High temperature steam-only gasification of woody biomass. Appl. Energy 2010, 87, 791-798. [CrossRef]

20. Meng, X.; de Jong, W.; Fu, N.; Verkooijen, A.H.M. Biomass gasification in a $100 \mathrm{kWth}$ steam-oxygen blown circulating fluidized bed gasifier: Effects of operational conditions on product gas distribution and tar formation. Biomass Bioenergy 2011, 35, 2910-2924. [CrossRef]

21. Howaniec, N.; Smoliński, A. Steam gasification of energy crops of high cultivation potential in Poland to hydrogen-rich gas. Int. J. Hydrogen Energy 2011, 36, 2038-2043. [CrossRef]

22. Murakami, K.; Kasai, K.; Kato, T.; Sugawarab, K. Conversion of rice straw into valuable products by hydrothermal treatment and steam gasification. Fuel 2012, 93, 37-43. [CrossRef]

23. Mikeska, M.; Najser, J.; Peer, V.; Frantik, J.; Kielar, J. Quality assessment of gas produced from different types of biomass pellets in gasification process. Energy Explor. Exploit. 2020, 38, 406-416. [CrossRef]

24. Schweitzer, D.; Gredinger, A.; Schmid, M.; Waizmann, G.; Beirow, M.; Spörl, R.; Scheffknecht, G. Steam gasification of wood pellets, sewage sludge and manure: Gasification performance and concentration of impurities. Bioresour. Technol. 2018, 111, 308-319. [CrossRef]

25. Hussein, M.S.; Burra, K.G.; Amano, R.S.; Gupta, A.K. Effect of oxygen addition in steam gasification of chicken manure. Fuel 2017, 189, 428-435. [CrossRef]

26. Roche, E.; de Andrés, J.M.; Narros, A.; Rodríguez, M.E. Air and air-steam gasification of sewage sludge. The influence of dolomite and throughput in tar production and composition. Fuel 2014, 115, 54-61. [CrossRef]

27. Wei, L.; Xu, S.; Zhang, L.; Liu, C.; Zhu, H.; Liu, S. Steam gasification of biomass for hydrogen-rich gas in a free-fall reactor. Int. J. Hydrogen Energy 2007, 32, 24-31. [CrossRef]

28. Nipattummakul, N.; Ahmed, I.I.; Gupta, A.K.; Kerdsuwan, S. Hydrogen and syngas yield from residual branches of oil palm tree using steam gasification. Int. J. Hydrogen Energy 2011, 36, 3835-3843. [CrossRef]

29. Kumar, A.; Eskridge, K.; Jones, D.B.; Hanna, M.A. Steam-air fluidized bed gasification of distillers grains: Effects of steam to biomass ratio, equivalence ratio and gasification temperature. Bioresour. Technol. 2009, 100, 2062-2068. [CrossRef]

30. Wilson, L.; John, G.R.; Mhilu, C.F.; Yang, W.; Blasiak, W. Coffee husks gasification using high temperature air/steam agent. Fuel Process. Technol. 2010, 91, 1330-1337. [CrossRef]

31. Howaniec, N.; Smoliński, A.; Stańczyk, K.; Pichlak., M. Steam co-gasification of coal and biomass derived chars with synergy effect as an innovative way of hydrogen-rich gas production. Int. J. Hydrogen Energy 2011, 36, 14455-14463. [CrossRef]

32. Yu, J.; Tian, F.-J.; Chow, M.C.; McKenzie, L.J.; Li, C.-Z. Effect of iron on the gasification of Victorian brown coal with steam: Enhancement of hydrogen production. Fuel 2006, 85, 127-133. [CrossRef]

33. Zheng, X.; Ying, Z.; Wang, B.; Chen, C. Hydrogen and syngas production from municipal solid waste (MSW) gasification via reusing $\mathrm{CO}_{2}$. Appl. Therm. Eng. 2018, 144, 242-247. [CrossRef]

34. Pfeifer, C.; Koppatz, S.; Hofbauer, H. Steam gasification of various feedstocks at a dual fluidised bed gasifier: Impacts of operation conditions and bed materials. Biomass Conv. Bioref. 2011, 1, 39-53. [CrossRef]

35. Pinto, F.; Franco, C.; André, R.N.; Tavares, C.; Dias, M.; Gulyurtlu, I.; Cabrita, I. Effect of experimental conditions on co-gasification of coal, biomass and plastics wastes with air/steam mixtures in a fluidized bed system. Fuel 2003, 82, 1967-1976. [CrossRef]

36. Stasiek, J.; Szkodo, M. Thermochemical conversion of biomass and municipal waste into useful energy using advanced hitag/hitsg technology. Energies 2020, 13, 4218. [CrossRef] 
37. Udomsirichakorn, J.; Basu, P.; Salam, P.A.; Acharya, B. Effect of $\mathrm{CaO}$ on tar reforming to hydrogen-enriched gas with in-process $\mathrm{CO} 2$ capture in a bubbling fluidized bed biomass steam gasifier. Int. J. Hydrogen Energy 2013, 38, 14495-14504. [CrossRef]

38. Erkiaga, A.; Lopez, G.; Amutio, M.; Bilbao, J.; Olazar, M. Steam gasification of biomass in a conical spouted bed reactor with olivine and $\gamma$-alumina as primary catalysts. Fuel Process. Technol. 2013, 116, $292-299$. [CrossRef]

39. Chang, A.C.C.; Chang, H.F.; Lin, F.J.; Lin, K.H.; Chen, C.H. Biomass gasification for hydrogen production. Int. J. Hydrogen Energy 2011, 36, 14252-14260. [CrossRef]

40. Karmakar, M.K.; Datta, A.B. Generation of hydrogen rich gas through fluidized bed gasification of biomass. Bioresour. Technol. 2011, 102, 1907-1913. [CrossRef]

41. Salman, C.A.; Omer, C.B. Process modelling and simulation of waste gasification-based flexible polygeneration facilities for power, heat and biofuels production. Energies 2020, 13, 4264. [CrossRef]

42. Schuster, G.; Löffler, G.; Weigl, K.; Hofbauer, H. Biomass steam gasification-An extensive parametric modeling study. Bioresour. Technol. 2001, 77, 71-79. [CrossRef]

43. Sharma, S.; Sheth, P.N. Air-steam biomass gasification: Experiments, modeling and simulation. Energy Convers. Manag. 2016, 110, 307-318. [CrossRef]

44. Kuo, P.C.; Wu, W. Design, optimization and energetic efficiency of producing hydrogen-rich gas from biomass steam gasification. Energies 2015, 8, 94-110. [CrossRef]

45. Najser, J.; Buryan, P.; Skoblia, S.; Frantik, J.; Kielar, J.; Peer, V. Problems related to gasification of biomass-Properties of solid pollutants in raw gas. Energies 2019, 12, 963. [CrossRef]

(C) 2020 by the authors. Licensee MDPI, Basel, Switzerland. This article is an open access article distributed under the terms and conditions of the Creative Commons Attribution (CC BY) license (http://creativecommons.org/licenses/by/4.0/). 